\title{
Removal of Cadmium from Simulated Wastewater using Rotating Tubular Packed Bed Electrochemical Reactor: Optimization through Response Surface Methodology
}

\author{
Zahraa N.abbas ${ }^{a}$, Ali H. Abbar ${ }^{a *}$ \\ ${ }^{a}$ Chemical Engineering Department -Faculty of Engineering - University of Al-Qadisiyah-Iraq
}

\section{A R T I C L E I N F O}

\section{Article history:}

Received 17 March 2020

Received in revised form 15 May 2020

Accepted 27 May 2020

\section{Keywords:}

Three-dimensional electrodes

Rotating cylinder electrode

Woven screens

cadmium removal

Response surface methodology

\begin{abstract}
A B S T R A C T
A rotating tubular packed bed electrochemical reactor was used for the electrochemical removal of cadmium (Cd) from simulated wastewater. Impacts of electrolysis operating parameters: current (0.56-2.8 A), rotation speed (100-500 rpm), initial cadmium concentration (20-100 ppm), and $\mathrm{pH}(3-9)$ were investigated. Response surface methodology and Box-Behnken design were used for optimizing the process parameters where cadmium Removal Efficiency (RE \%) was selected as a response function. Findings of the present work suggested that currently has a main impact on the removal efficiency of cadmium followed by rotation speed, then concentration and $\mathrm{pH}$. The results of the regression analysis showed that experimental data could be fitted to a second-degree polynomial model with value of the determination coefficient $\left(\mathrm{R}^{2}\right)$ equal to $91.8 \%$. Optimal conditions for process parameters based on the RSM model were initial Cd concentration of $32.0 \mathrm{ppm}$, current of $2.8 \mathrm{~A}$, rotation speed of $371 \mathrm{rpm}$ and $\mathrm{pH}=3$, where a final cadmium concentration less than $0.3 \mathrm{ppm}$ was obtained after $30 \mathrm{~min}$ of electrolysis process ( $\mathrm{RE}=99.28 \%$ ).
\end{abstract}

(C) 2020 University of Al-Qadisiyah. All rights reserved

\section{Introduction}

Among heavy metals, Cd can be considered as a very dangerous for human health, so it has been blacklisted in European society [1, 2]. Cadmium is a non-essential and non-degradable mineral and hence it was considered as a major pollutant of water environments resulting in very damaging effects on life. It comes to the aquatic environment from industries such as ceramics, paper, electroplating, batteries, combustion and mining units, dyes, PVC, and many other manufacturing industries Yaqub and Shaikh [3]. Environmental Protection Agency (EPA) considered the chronic exposure to cadmium results in potentially poor kidney function which known as "itai-itai" disease, with symptoms prone to osteoporosis and other bone diseases $[4,5]$. The regulatory restrictions for cadmium discharge to liquid wastes are very strict due to its toxicity; therefore the treatment of these liquid wastes is obligatory before they are discharged into the sewers to maintain the concentration of cadmium below the specified level Barnes [6]. Several conventional methods of treatment have been used to remove cadmium such as ion exchange, adsorption, reverse osmosis, chemical precipitation, biosorption, electrodialysis, ion exchange-based membrane separation, and electrochemical deposition $\mathrm{Fu}$ and Q. Wang [7]. Adsorption and chemical precipitation techniques suffered from a number of shortcomings caused by the high amount of

\footnotetext{
* Corresponding author. Tel.: +964(0)7803280891

E-mail address : ali.abbar@qu.edu.iq ( Ali H. Abbar)
} 


\begin{tabular}{|c|c|c|c|}
\hline \multicolumn{4}{|c|}{ Nomenclature } \\
\hline Adj. MS & Adjusted mean of the square & $\mathrm{k}$ & Number of process variables \\
\hline adj. $R^{2}$ & Adjusted coefficient of multiple correlation & $\mathrm{N}$ & Number of runs \\
\hline Adj. SS & Adjusted sum of the square & OFAT & One-factor-at-a-time \\
\hline$a_{i}$ & The first-class(linear) major effect & PI & Prediction interval. \\
\hline$a_{\mathrm{ii}}$ & Second-class major effect & pred. $\mathrm{R}^{2}$ & Predicted multiple correlation coefficient \\
\hline $\mathrm{a}_{\mathrm{ij}}$ & The interaction effect & $\mathrm{Pt}$ & Platinum \\
\hline ANOVA & Analysis of variance & $\mathrm{RE}$ & Removal Efficiency (\%) \\
\hline$a_{0}$ & The code of intercept & RSM & Response surface methodology \\
\hline $\mathrm{BBD}$ & Box-Behnken Design & S & Standard Error of the Regression \\
\hline BDD & Boron Doped diamond & SE & Standard error of mean \\
\hline $\mathrm{Cd}$ & Cadmium & Seq. SS & Sum of square \\
\hline $\mathrm{CE}$ & Current Efficiency (\%) & $\mathrm{t}$ & Time, s \\
\hline CI & Confidence interval & $\mathrm{V}$ & Volume of electrolyte, $\mathrm{cm}^{3}$ \\
\hline $\mathrm{cp}$ & Reiterated number of the central point & $\mathrm{x}_{1}$ & Coded value of cadmium Concentration \\
\hline Contr. & Percentage contribution for each parameter, $\%$ & $\mathrm{X} 1$ & Concentration of cadmium, ppm \\
\hline $\mathrm{D}_{\mathrm{F}}$ & The desirability function & $\mathrm{x}_{2}$ & Coded value of current \\
\hline DOF & Degree of freedom & $\mathrm{X} 2$ & Current, A \\
\hline E & Voltage of cell, Volt & $\mathrm{x}_{3}$ & Coded value of rotation speed \\
\hline EC & Energy Consumption, $\mathrm{kWh} / \mathrm{kg} \mathrm{Cd}$ & $\mathrm{X} 3$ & Rotation speed, rpm \\
\hline EPA & Environmental Protection Agency & $\mathrm{x}_{4}$ & Coded value of $\mathrm{pH}$ \\
\hline $\mathrm{F}$ & Faraday Constant, $\mathrm{A} \mathrm{s} \mathrm{mol}^{-1}$ & $\mathrm{X} 4$ & $\mathrm{pH}$ \\
\hline I & Current applied, A & $\mathrm{Y}$ & Represents the dependent variable (RE, \%) \\
\hline
\end{tabular}

chemicals used and the requirements for the sludge removal. Hence, these solutions only move the problem from the liquid to the solid phase Zamboulis et al. [8]. Therefore, other methods should be improved to increase the demand for more competitive, economical, and effective treatment methods to remove or return metals like cadmium from industrial effluents Droste et al. [9].

In latest years, electrochemical methods have received large interest because of the distinguishing features of compatibility environmental, safety, and variety. Electrochemical techniques compete with other conventional technologies, like ion exchange, evaporation, solvent extraction, and precipitation. Electrochemical methods are unique in their ability to recover pure metal for recycling Jüttner et al. [10]. The utilizing of electrochemical techniques in environmental treatment are growing, because of the utilizing of porous materials in the design of electrochemical reactors as three dimensional electrodes. In fact, the high surface area as well as the high mass transfer rate are considered to be the major advantages of these electrodes Abdel-Salam et al. [11].

Electrochemical methods are considered as clean, environmentally engaging technologies since the major reaction reagent is the electron. Economically, the electrochemical method is valuable due to the low energy consumption compared with the well-known techniques [10]. In addition, the possibility of applying the automatization in controlling of current during the electrodeposition process results in lowering the workload requirements Tonini et al. [12].

Different types of packed bed electrochemical reactors were used to achieve the electrochemical removal of heavy metals from wastewater, such as fixed bed cathodes (flow-by and flow-through configurations) and packed bed rotating cathodes [13-18]. Heavy metals removal was carried out formerly by using rotating cylinder electrodes with a packed bed in the form of woven wire meshes and reticulated vitreous carbon (RVC) [15], $[19,20]$. Previous studies showed that the packed bed rotating cylinder electrode of woven wire meshes when compared with other types of rotating cylinder electrodes has a value of mass transport coefficient greater approximately by three times than those observed in a smooth rotating electrode as a result of greater turbulence-promoting action of the meshes Abbar et al. [19]. However, the thickness of the electrode should be kept low to ensure that the whole bed is operating under minimal current conditions Kreysa and Brandner [21]. Yet, using the electrodes of the packed bed rotating cylinder electrode (PBRCE) composed from woven wire meshes had been evidenced to be more effective than the conventional designs [15], [19]. They offer higher specific surface area which permits achieving higher removal rate of metal ion even at more dilute effluent.

Throughout previous studies linked to electrochemical removal of heavy metals, a traditional One-Factor-At-a-Time method (OFAT) was commonly used. It changes just one variable at a time, while others remain unchanged. However, the interactions of the variables could not be specified by the OFAT experiments. In comparison with OFAT approach, a proposed method based on an experimental design approach is a more effective approach for estimating the impact of two or more variables on the response in addition to their interactions. The main advantage of an experimental design approach is requiring fewer resources (experiments, time and materials) to obtain the necessary data. In addition, the analysis of the effects of each factor is made more successful utilizing experimental design techniques Cheng et al. [22]. Response surface methodology (RSM) is an important subject in the statistical design of the experiments. It was successfully applied in several wastewater treatment systems, such as adsorption [23, 24], chlorine disinfection [25] , electrocoagulation [26] , Fenton-related process[27], and electrochemical oxidation [28]. RSM was widely used as an optimization system in other processes such as biofluid separation [29, 30]. It consists of a set of statistical and mathematical techniques that can be used effectively to model and analyze a variety of difficulties in which various parameters have an influence on the response of interest. The goal of RSM is to estimate the relative impact of various parameters and finally to achieve the best operating conditions by optimizing this response Thirugnanasambandham et al. [31]. In our previous work, we studied the removal of copper utilizing a tubular packed bed woven screens electrode, where a good performance of this design had been reported Hemeidan and Abbar [32]. The main purpose of the work underway is to evaluate the efficiency of this design in the removal of cadmium by optimizing process parameters like initial metal concentration, current, rotational speed, and $\mathrm{pH}$ so as to achieve larger removal efficiency as possible as in cadmium removal from simulated synthetic wastewater."Box-Behnken Design (BBD)" of the response surface methodology was adopted as an optimization technique, where no previous works have been reported on the optimization of cadmium removal using a tubular packed bed woven screens electrode. 


\section{Experimental work}

The experimental runs were conducted at $0.5 \mathrm{~L}$ Perspex-a cylindrical electrolytic cell. The working electrode (cathode) was a rotating tubular bed electrode made of 316 stainless steel woven screens wrapped around a stainless steel hollow cylinder serving as a current feeder. The hollow cylinder (current feeder) was opened at the bottom and closed at the top. It was perforated with a total of (55) holes with diameter $(6 \mathrm{~mm})$ distributed uniformly on the lateral surface of the cylinder. The cathode feeder has an outer diameter $(35 \mathrm{~mm})$, inner diameter $(28 \mathrm{~mm})$ with total length $(60 \mathrm{~mm})$. The lower part of this feeder is jointed with a Teflon sleeve has a diameter $(55 \mathrm{~mm})$ and thickness $(12 \mathrm{~mm})$, Whilst the upper part is joined by a Teflon sleeve has a diameter $(55 \mathrm{~mm})$ and thickness of $(17 \mathrm{~mm})$ so as to fix the wrapped woven screens sheets on the current feeder. The cathode current feeder was connected to the variable speed motor shaft by means of a stainless steel rod ( $7 \mathrm{~mm}$ in diameter and $100 \mathrm{~mm}$ in length) mounted to the cathode feeder. The cathode has an apparent surface area $\left(76.34 \mathrm{~cm}^{2}\right)$ (45 mm diameter and $53 \mathrm{~mm}$ long). Outer graphite cylinder with dimensions (90 mm inner diameter, $5 \mathrm{~mm}$ thickness, and $66 \mathrm{~mm}$ long) having a surface area of $186.92 \mathrm{~cm}^{2}$ was used as outside anode while a central graphite rod having dimensions $(60 \mathrm{~mm}$ length and $20 \mathrm{~mm}$ diameter) was used as inside anode. For ensuring a uniform primary current distribution, the three electrodes (cathode, outer anode, and inside anode) were concentric in the cell body. Figure 1 displays the schematic diagram of the experimental setup.

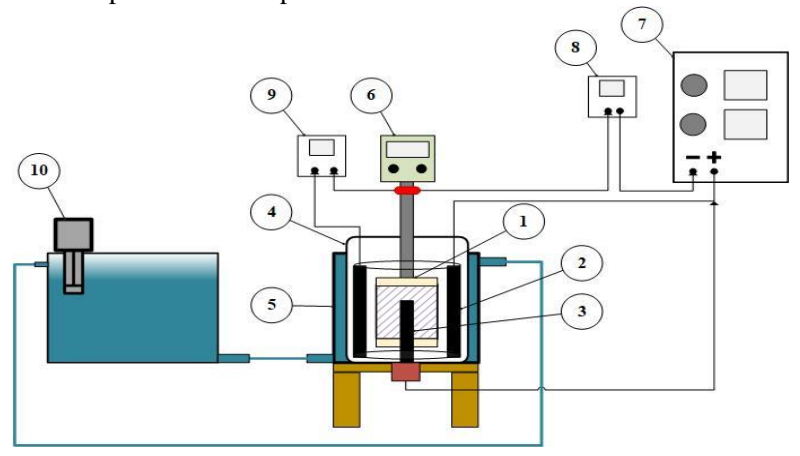

Figure 1. The schematic diagram for the experimental setup:- 1) cathode, 2) outside anode, 3) inside anode, 4) cell body, 5) jacket, 6) electrical motor, 7) power supply, 8) Ammeter, 9) voltmeter, 10) water bath circulator.

The cathode was cleaned with (1 $\mathrm{M}$ of nitric acid solution) in an ultrasound cleaner before starting any run to remove the cadmium deposits from older run, then washed with distilled water again.

Cadmium sulfate $\left(3 \mathrm{CdSO}_{4} .7 \mathrm{H}_{2} \mathrm{O}\right)$ was used as a source of cadmium ion while sodium sulfate $\left(\mathrm{Na}_{2} \mathrm{SO}_{4}\right)$ was used as a supporting electrolyte. All chemicals were of reagent grade. Doubly distilled water was used for preparing electrolytic solutions containing cadmium ions dissolved in $0.5 \mathrm{M} \mathrm{Na}_{2} \mathrm{SO}_{4}$ at concentrations $(20,60,100 \mathrm{ppm})$. The final $\mathrm{pH}$ of electrolytic solutions has been adjusted by using $(1 \mathrm{M}$ of $\mathrm{NaOH}$ or $1 \mathrm{M}$ of $\mathrm{H}_{2} \mathrm{SO}_{4}$ ). All runs were carried out at a fixed temperature of $25 \pm 2^{\circ} \mathrm{C}$.

Stainless steel screens having a mesh number of 30 were used. The properties of these screens are presented in Table 1. Screen porosity $(\varepsilon)$ was evaluated by determining the ratio of the weight of screen to its area $\left(a_{s}\right)$ and applying Eq. 1, then screen specific surface area(s) was computed based on Eq. 2 [33]:

$$
\varepsilon=1-\frac{m_{s}}{\rho_{s} l a_{s}}
$$

$$
s=(1-\varepsilon) r
$$

Where $\left(m_{s} / a_{s}\right)$ is the weight /area density, $(r)$ is the surface to volume ratio of the screen wire equal to $(4 / \mathrm{d}),\left(\rho_{\mathrm{s}}\right)$ is the density of stainless steel 316-AISI equal to $8.027 \mathrm{gm} / \mathrm{cm}^{3}$ [34], $(l)$ is the screen thickness equal to $2 \mathrm{~d}$. The woven screen type was identified utilizing Olympus BX51M with DP70 digital camera system whereas a digital calliper was utilized to calculate wire diameter (d).

Table 1. Properties of Screen

\begin{tabular}{cl}
\hline Mesh No. (wire/inch) & $\mathbf{3 0}$ \\
\hline Type of woven & Plain square \\
$\mathrm{d}, \mathrm{cm}$ & 0.030 \\
$\left(\mathrm{~m}_{\mathrm{s}} / \mathrm{a}_{\mathrm{s}}\right), \mathrm{g} / \mathrm{cm}^{2}$ & 0.1237 \\
$\varepsilon$ & 0.7146 \\
$s, \mathrm{~cm}^{-1}$ & 38.06 \\
\hline
\end{tabular}

Removal Efficiency (RE, \%) was determined using the following equation. [35]:

$$
R E=\frac{C_{i}-C_{f}}{C_{i}} \times 100
$$

Where, $\mathrm{C}_{\mathrm{f}}$ is the final cadmium concentration after an interval of time $(\Delta t), C_{i}$ is the initial cadmium concentration.

Current Efficiency (CE \%) is the ratio of the actual mass of cadmium ion electrodeposited on the cathode surface to the theoretical mass that could be electrodeposited according to "Faraday's law", It can be determined using the following equation [35]:

$C E=\frac{100 * z_{i} * F * \Delta m}{M_{i} * I * \Delta t}$

Where, $I$ is the applied current (A); $F$ is the Faraday constant (96487A $\mathrm{s} / \mathrm{mol}) ; \mathrm{M}_{\mathrm{i}}$ is the molar mass of cadmium $(112.41 \mathrm{~g} / \mathrm{mol}) ; \Delta \mathrm{m}$ is the mass of cadmium electrodeposited at a period of electrolysis time $(\mathrm{g}) ; \mathrm{z}_{\mathrm{i}}$ is the number of electrons, and $\Delta t$ is the electrolysis time (s).

The major item in evaluating the cost of an electrochemical process is the specific energy required for operating the electrochemical reactor. It is defined as the energy required for the production or treatment of a certain quantity of a substance on a molar, mass, or volume basis. The energy consumption can be evaluated according to the following equation [35]:

$$
E C=\frac{2.788 \times 10^{-4} E I \Delta t}{\Delta m}
$$

Where $E$ is the voltage of the cell (Volt).

\subsection{Design of experiments}

The relationship between both the response of process and its variables can be determined by applying a series of mathematical and statistical methods adopted by the RSM [36]. In the present study, the 4-factor 3-level Box-Behnken experimental design was used to verify and monitor the variables that affect the removal of cadmium from simulated wastewater. Initial concentration of cadmium ion (X1) Current (X2), rotation speed (X3), and $\mathrm{pH}(\mathrm{X} 4)$ were taken as process variables, whereas removal efficiency of $\mathrm{Cd}(\mathrm{RE} \%)$ was taken as a response function. The scales of process variables were coded as 1 (high level), -1 (low level) and 0 (middle or central point) [37]. Table 2 illustrates the process variables with their 
chosen levels. Box-Behnken improves designs to get the suitable quadratic model with the required statistical properties by using only a part of the runs needed for a 3-level factorial. The number of runs $(\mathrm{N})$ required for performing Box - Behnken design can be calculated by the following equation [38]:

$$
\mathrm{N}=2 \mathrm{k}(\mathrm{k}-1)+\mathrm{cp}
$$

Where $\mathrm{cp}$ is the reiterated number of the central point and $\mathrm{k}$ is the number of process variables.

In the present study, twenty-seven runs were performed to test the impacts of process variables on the removal efficiency of cadmium. Table 3 illustrates the BBD proposed for the present research. The selected value of current in the present work was ranged from 0.56 to $2.8 \mathrm{~A}$ which corresponding to an anodic current density ranged from 3 to $15 \mathrm{~mA} / \mathrm{cm}^{2}$ based on the area of the outside anode to ensure less electrical resistance due to oxygen evolution on the anode.

Table 2. Process variables with their levels for $\mathrm{Cd}$ removal

\begin{tabular}{llll} 
Process parameters & \multicolumn{3}{l}{ range in Box-Behnken design } \\
\hline Coded levels & Low $(-1)$ & Middle $(0)$ & High $(+1)$ \\
X1-Concentration(ppm) & 20 & 60 & 100 \\
X2- Current(A) & 0.56 & 1.68 & 2.8 \\
X3-Rotation speed(rpm) & 100 & 300 & 500 \\
X4-pH & 3 & 6 & 9 \\
\hline
\end{tabular}

Table 3. Box- Behnken experimental design

\begin{tabular}{|c|c|c|c|c|c|c|c|c|c|}
\hline \multirow[b]{2}{*}{$\begin{array}{l}\mathbf{R} \\
\mathbf{U} \\
\mathbf{N} \\
\end{array}$} & \multirow[b]{2}{*}{ Blk } & \multicolumn{4}{|c|}{ Coded value } & \multicolumn{3}{|c|}{ Real value } & \multirow[b]{2}{*}{$\begin{array}{l}\text { pH } \\
(\mathrm{X4}) \\
\end{array}$} \\
\hline & & $x_{1}$ & $x_{2}$ & $x_{3}$ & $x_{4}$ & $\begin{array}{l}\text { Conc. } \\
\text { (ppm) } \\
\text { (X1) }\end{array}$ & $\begin{array}{l}\text { Cur. } \\
\text { (A) } \\
\text { (X2) } \\
\end{array}$ & $\begin{array}{l}\text { Rot. } \\
\text { (rpm) } \\
\text { (X3) }\end{array}$ & \\
\hline 1 & 1 & -1 & 1 & 0 & 0 & 20 & 2.8 & 300 & 6 \\
\hline 2 & 1 & -1 & 0 & 0 & 1 & 20 & 1.68 & 300 & 9 \\
\hline 3 & 1 & 0 & -1 & -1 & 0 & 60 & 0.56 & 100 & 6 \\
\hline 4 & 1 & 1 & 0 & 1 & 0 & 100 & 1.68 & 500 & 6 \\
\hline 5 & 1 & 0 & -1 & 1 & 0 & 60 & 0.56 & 500 & 6 \\
\hline 6 & 1 & 1 & 1 & 0 & 0 & 100 & 2.8 & 300 & 6 \\
\hline 7 & 1 & 1 & 0 & -1 & 0 & 100 & 1.68 & 100 & 6 \\
\hline 8 & 1 & 0 & 1 & 1 & 0 & 60 & 2.8 & 500 & 6 \\
\hline 9 & 1 & 0 & -1 & 0 & -1 & 60 & 0.56 & 300 & 3 \\
\hline 10 & 1 & 0 & 0 & -1 & -1 & 60 & 1.68 & 100 & 3 \\
\hline 11 & 1 & -1 & 0 & 0 & -1 & 20 & 1.68 & 300 & 3 \\
\hline 12 & 1 & 0 & 0 & 1 & 1 & 60 & 1.68 & 500 & 9 \\
\hline 13 & 1 & 0 & 0 & 0 & 0 & 60 & 1.68 & 300 & 6 \\
\hline 14 & 1 & -1 & 0 & -1 & 0 & 20 & 1.68 & 100 & 6 \\
\hline 15 & 1 & 0 & 1 & 0 & 1 & 60 & 2.8 & 300 & 9 \\
\hline 16 & 1 & 0 & 0 & 0 & 0 & 60 & 1.68 & 300 & 6 \\
\hline 17 & 1 & 1 & 0 & 0 & -1 & 100 & 1.68 & 300 & 3 \\
\hline 18 & 1 & -1 & -1 & 0 & 0 & 20 & 0.56 & 300 & 6 \\
\hline 19 & 1 & 0 & 1 & 0 & -1 & 60 & 2.8 & 300 & 3 \\
\hline 20 & 1 & 0 & -1 & 0 & 1 & 60 & 0.56 & 300 & 9 \\
\hline 21 & 1 & 0 & 0 & 1 & -1 & 60 & 1.68 & 500 & 3 \\
\hline 22 & 1 & -1 & 0 & 1 & 0 & 20 & 1.68 & 500 & 6 \\
\hline 23 & 1 & 1 & -1 & 0 & 0 & 100 & 0.56 & 300 & 6 \\
\hline 24 & 1 & 0 & 0 & 0 & 0 & 60 & 1.68 & 300 & 6 \\
\hline 25 & 1 & 0 & 0 & -1 & 1 & 60 & 1.68 & 100 & 9 \\
\hline 26 & 1 & 1 & 0 & 0 & 1 & 100 & 1.68 & 300 & 9 \\
\hline 27 & 1 & 0 & 1 & -1 & 0 & 60 & 2.8 & 100 & 6 \\
\hline
\end{tabular}

A second order polynomial model can be adopted based on BBD were fitting the interaction terms with the experimental data can be described by the following equation [39]:

$$
Y=a_{0}+\sum a_{i} x_{i}+\sum a_{i i} x_{i}^{2}+\sum a_{i j} x_{i} x_{j}
$$

Where, $\mathrm{Y}$ represents the dependent variable (RE), $\mathrm{i}$ and $\mathrm{j}$ are the index numbers for patterns, $a_{0}$ is the intercept term, $x_{1}, x_{2} \ldots x_{k}$ are the independent variables (process variables) in coded form. $a_{i}$ is the firstorder(linear) principal impact, $a_{i i}$ second-order main impact and $a_{i j}$ is the interaction impact. Analysis of variance was performed then the regression coefficient $\left(\mathrm{R}^{2}\right)$ was estimated to confirm the goodness of the model fit

\section{Results and discussion}

\subsection{The Analysis of statistics}

In this experimental program, twenty-seven statistically structured batch runs have been completed for various combinations of process parameters in order to optimize and evaluate the potential effects of independent variables on removal efficiency. Table 4 displays experimental results, such as removal efficiency, energy consumption, and current efficiency at operating time of $30 \mathrm{~min}$. It is shown that cadmium removal efficiency is within the range of $83-99 \%$, while current efficiency is in the range of $(0.26-5.64 \%)$ and energy consumption in the range of (963.2-30.5) KWh / kg Cd.

Table 4. The experimental results of "Box-Behnken design" for the cadmium removal

U BIk Conc. Cur. Rot. $p$ RE $\frac{\text { RE\% }}{\text { E }}$ CE $\quad$ EC

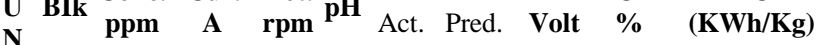

\begin{tabular}{lllllllllll}
\hline 1 & 1 & 20 & 2.8 & 300 & 6 & 99 & 98.4 & 5.3 & 0.26 & 963.2
\end{tabular}

$\begin{array}{lllllllllll}2 & 1 & 20 & 1.68 & 300 & 9 & 93 & 92.4 & 4.9 & 0.41 & 551.9\end{array}$

$\begin{array}{lllllllllll}3 & 1 & 60 & 0.56 & 100 & 6 & 84 & 82.6 & 3.3 & 3.46 & 46.6\end{array}$

$\begin{array}{lllllllllll}4 & 1 & 100 & 1.68 & 500 & 6 & 92 & 91.3 & 4.3 & 2.10 & 90.6\end{array}$

$\begin{array}{lllllllllll}5 & 1 & 60 & 0.56 & 500 & 6 & 94 & 91.8 & 2.9 & 3.87 & 36.0\end{array}$

$\begin{array}{lllllllllll}6 & 1 & 100 & 2.8 & 300 & 6 & 97 & 95.6 & 5.3 & 1.32 & 186.1\end{array}$

$\begin{array}{lllllllllll}7 & 1 & 100 & 1.68 & 100 & 6 & 87 & 87.8 & 4.3 & 1.96 & 90.6\end{array}$

$\begin{array}{lllllllllll}8 & 1 & 60 & 2.8 & 500 & 6 & 98 & 98.2 & 5.7 & 0.81 & 266.9\end{array}$

$\begin{array}{lllllllllll}9 & 1 & 60 & 0.56 & 300 & 3 & 90 & 90.2 & 4.3 & 3.73 & 54.9\end{array}$

$\begin{array}{lllllllllll}10 & 1 & 60 & 1.68 & 100 & 3 & 93 & 92.5 & 5.4 & 1.27 & 169.3\end{array}$

$\begin{array}{lllllllllll}11 & 1 & 20 & 1.68 & 300 & 3 & 97 & 94.7 & 4.7 & 0.43 & 523.7\end{array}$

$\begin{array}{lllllllllll}12 & 1 & 60 & 1.68 & 500 & 9 & 94 & 95.0 & 4.7 & 1.29 & 174.9\end{array}$

$\begin{array}{lllllllllll}13 & 1 & 60 & 1.68 & 300 & 6 & 92 & 92.3 & 4.4 & 1.27 & 164.0\end{array}$

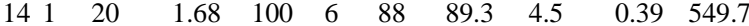

$\begin{array}{lllllllllll}15 & 1 & 60 & 2.8 & 300 & 9 & 98 & 98.8 & 6.3 & 0.81 & 368.7\end{array}$

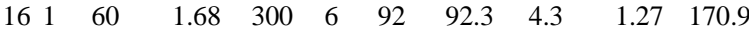

$\begin{array}{lllllllllll}17 & 1 & 100 & 1.68 & 300 & 3 & 93 & 91.8 & 4.5 & 2.10 & 95.0\end{array}$

$\begin{array}{lllllllllll}18 & 1 & 20 & 0.56 & 300 & 6 & 85 & 87.5 & 3.3 & 1.13 & 134.3\end{array}$

$\begin{array}{lllllllllll}19 & 1 & 60 & 2.8 & 300 & 3 & 99 & 99.7 & 6.4 & 0.82 & 374.6\end{array}$

$\begin{array}{lllllllllll}20 & 1 & 60 & 0.56 & 300 & 9 & 87 & 86.6 & 3.3 & 3.59 & 44.2\end{array}$

$\begin{array}{lllllllllll}21 & 1 & 60 & 1.68 & 500 & 3 & 93 & 96.2 & 4.9 & 1.28 & 183.5\end{array}$

$\begin{array}{lllllllllll}22 & 1 & 20 & 1.68 & 500 & 6 & 96 & 95.4 & 5.1 & 0.43 & 573.1\end{array}$

$\begin{array}{lllllllllll}23 & 1 & 100 & 0.56 & 300 & 6 & 83 & 84.7 & 3.6 & 5.64 & 30.5\end{array}$

$\begin{array}{lllllllllll}24 & 1 & 60 & 1.68 & 300 & 6 & 92 & 92.3 & 4.4 & 1.27 & 168.6\end{array}$

$\begin{array}{lllllllllll}25 & 1 & 60 & 1.68 & 100 & 9 & 91 & 89.3 & 4.5 & 1.25 & 172.4\end{array}$

$\begin{array}{lllllllllll}26 & 1 & 100 & 1.68 & 300 & 9 & 89 & 89.7 & 5.3 & 2.02 & 111.7\end{array}$

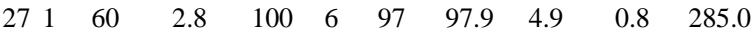

Minitab-17 software was used to analyze results of cadmium removal efficiency where an experimental relationship between $\mathrm{Cd}$ removal efficiency and process parameters was formulated by a quadratic model as response function (RE \%) in terms of un-coded (real) process variable units:

$\mathrm{RE} \%=84.25+0.0789 * \mathrm{X} 1+5.46 * \mathrm{X} 2+0.0306 * \mathrm{X} 3-2.39 * \mathrm{X} 4$

$-0.000779 *(\mathrm{X} 1)^{2}+0.362 *(\mathrm{X} 2)^{2}-0.000004 *(\mathrm{X} 3)^{2}$

$+0.1171 *(\mathrm{X} 4)^{2}+0.000001 * \mathrm{X} 1 * \mathrm{X} 2-0.000081 * \mathrm{X} 1 * \mathrm{X} 3$

$+0.00062 * \mathrm{X} 1 * \mathrm{X} 4-0.00993 * \mathrm{X} 2 * \mathrm{X} 3+0.193 * \mathrm{X} 2 * \mathrm{X} 4$

$+0.00083 * X 3 * X 4$

$\mathrm{X} 1, \mathrm{X} 2, \mathrm{X} 3$, and $\mathrm{X} 4$ are initial $\mathrm{Cd}$ concentration, current, rotation speed, and initial $\mathrm{pH}$ respectively, whereas the variables $\mathrm{X} 1 \mathrm{X} 2, \mathrm{X} 1 \mathrm{X} 3, \mathrm{X} 1 \mathrm{X} 4$, $\mathrm{X} 2 \mathrm{X} 3, \mathrm{X} 2 \mathrm{X} 4, \mathrm{X} 3 \mathrm{X} 4$ represent the interaction effect of all the parameters of the model. $(\mathrm{X} 1)^{2},(\mathrm{X} 2)^{2},(\mathrm{X} 3)^{2}$, and $(\mathrm{X} 4)^{2}$ are the estimates of the 
principal influence of variables like initial concentration of cadmium ion, current, rotation speed, and $\mathrm{pH}$.

Eq. (8) shows how the removal efficiency is affected by the individual variables (quadratic and linear) or double interactions. The values of positive coefficients revealed that the removal efficiency increased with the increasing of the related factors of these coefficients within the tested range while values of negative coefficients revealed the opposite effect. As can be seen, $\mathrm{pH}$ has a negative impact on removal performance, whereas current, rotation speed and concentration have been shown to have a positive effect. The results showed that the effects of the interactions are insignificant.

BBD adequacy was identified by use variance parts complemented by specific sources of variation [40]. The adequacy of the model in ANOVA analysis is recognized based on Fisher F-test and P-test. Many of the variance in response can be shown by the regression equation if the value of Fisher is higher. P-value test is used to determine whether $\mathrm{F}$ is high enough to suggest statistical significance $(90 \%)$. The percent of variability of the model could be explained if the P-value was less than 0.05 [41]. Table 5 illustrates ANOVA for the response surface model. In this table, degree of freedom (DOF ), sum of square (Seq. SS), percentage contribution (Contr. \%) for each parameter, adjusted sum of the square (Adj. SS), adjusted mean of the square (Adj. MS), Fisher-value, and P-test value were evaluated. Fisher-value of (9.59) and P- test value of (0.0001) were obtained, which illustrated the high significance of the regression model. The multiple correlation coefficient of the model was $91.80 \%$ conforming that the regression was statistically significant and only $(8.20 \%)$ of the full variations are not supported by the study. The adjusted multiple correlation coefficient (adj. $\mathrm{R}^{2}=82.23 \%$ ) was compatible with $\mathrm{R}^{2}$ in this model.

Table 5. Analysis of variance for cadmium removal

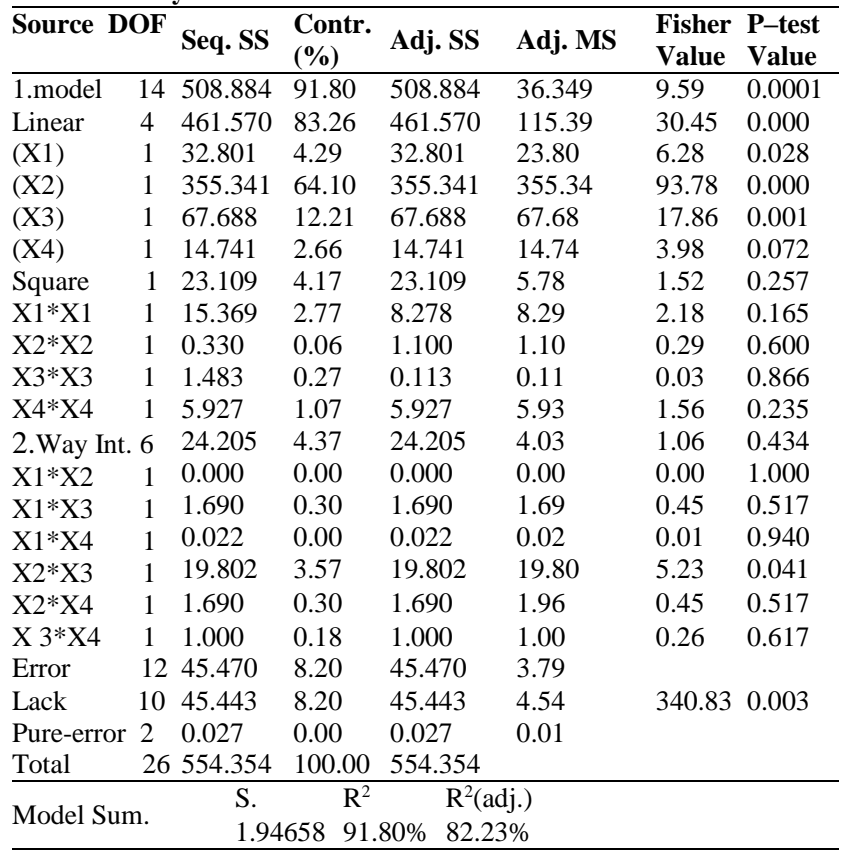

Results of ANOVA showed that the percent of contribution of the current was $64.10 \%$. This means that the current has a major impact on the removal efficiency of cadmium (RE, \%). The speed of rotation, the concentration of $\mathrm{Cd}$, and $\mathrm{pH}$ have low effects based on their percentage of contribution. The linear term has the main percent of contribution in the model with $83.26 \%$ followed by the interaction between the input variables with a contribution of $4.37 \%$, while the square has a small contribution $(4.17 \%)$. The results assure that current is the most significant factor revealing the system is under the mass transfer process.

\subsection{Impact of process parameters on the removal efficiency}

The interactive impact of the specified parameters and their effect on the response was evaluated by the graphic representation of statistical optimization utilizing RSM. Figures (2-a, 2-b) show the effect of the initial concentration of cadmium on the removal efficiency of cadmium for different current values $(0.56-2.8 \mathrm{~A})$ at constant rotation speed $(300 \mathrm{rpm})$ and $\mathrm{pH}$ (6). Figure (2-a) represents the response surface plot, while Figure (2-b) shows the corresponding contour plot. From the surface plot, it was observed that, at the current of $0.56 \mathrm{~A}$, the removal efficiency decreases as the initial concentration of cadmium increases. Similar behavior was observed as the current increased to 2.8A. At a concentration of 20ppm, the results show that increasing of current from 0.56 to $2.8 \mathrm{~A}$ leads to increase the cadmium removal efficiency from $85 \%$ to $99 \%$. At a concentration of $100 \mathrm{ppm}$, a similar progressive increase in the removal efficiency was observed as the current increased from 0.56 to $2.8 \mathrm{~A}$. The corresponding contour plot confirms that a maximum value of cadmium removal efficiency lies in a small area in which the current ranged between $2.3-2.8 \mathrm{~A}$ and cadmium ion concentration between 20-40 ppm.

The impact of $\mathrm{pH}$ on the removal efficiency of cadmium for different currents (0.56-2.8A) at a constant rotation speed of (300 rpm) and an initial concentration of (60 ppm) is shown in Figures (3-a, 3-b). The response surface plot Figure (3-a) shows that removal efficiency is slightly increased with decreasing of $\mathrm{pH}$. However, at $\mathrm{pH}=3$ and current $2.8 \mathrm{~A}$, a quick change in the removal efficiency was occurred reach to $98.9 \%$, while at $\mathrm{pH}=9$ and current $0.56 \mathrm{~A}$ the removal efficiency approached $87 \%$. The corresponding contour plot Figure (3-b) confirms that a maximum value of cadmium removal efficiency lies in a small area in which the current ranged between 2.3-2.8 $\mathrm{A}$ and $\mathrm{pH}$ 3-5.5.

Figures (4-a, 4-b) show the effect of rotation speed on the cadmium removal efficiency for various values of current (0.56-2.8A) at a constant concentration $(60 \mathrm{ppm})$ and $\mathrm{pH}(6)$. Figure (4-a) shows that the removal efficiency of $\mathrm{Cd}$ is quickly increased with increasing of current from 0.56 to $2.8 \mathrm{~A}$ at a rotation speed of $100 \mathrm{rpm}$. However, this increase became more sluggish at $500 \mathrm{rpm}$. Generally, increasing of rotation speed results in increasing of removal efficiency at low current with no significant effect at higher current. The removal efficiency was increased from $84 \%$ (at rotation speed of $100 \mathrm{rpm}$ and current of $0.56 \mathrm{~A}$ ) to $98 \%$ (at rotation speed of 500 rpm \& current of 2.8A). The corresponding contour plot Figure (4-b) confirms that a maximum value of cadmium removal efficiency lies in a small area in which the current ranged between 2.3-2.8A and rotation speed range $300-500 \mathrm{rpm}$. It was clarified that the surface response technique not only offers additional data on the interactions between factors but also leads to the estimation of possible optimum values for the variables in the study. 


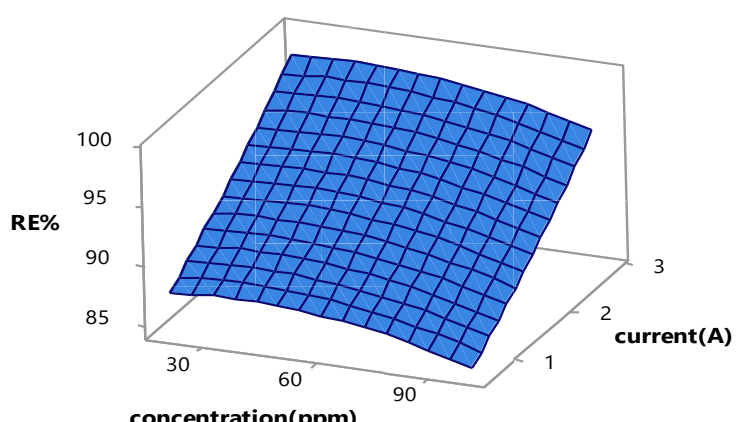

(a)

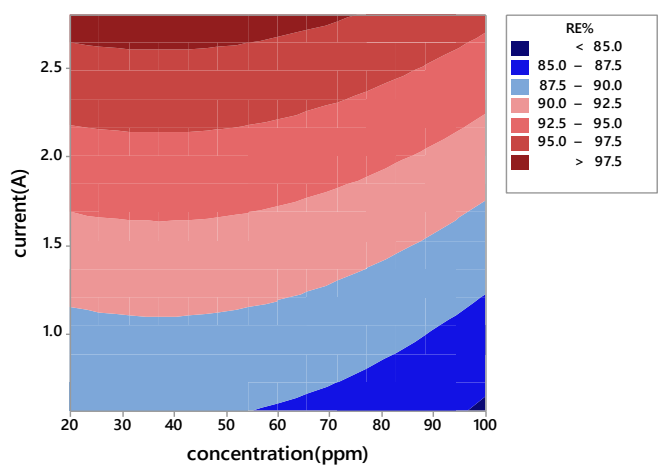

(b)

Figure 2. (a) Response surface plot, (b) contour plot for the impact of initial Cd concentration and current on the efficiency of Cd removal( hold values: rotation speed 300rpm, $\mathrm{pH}=6$ )

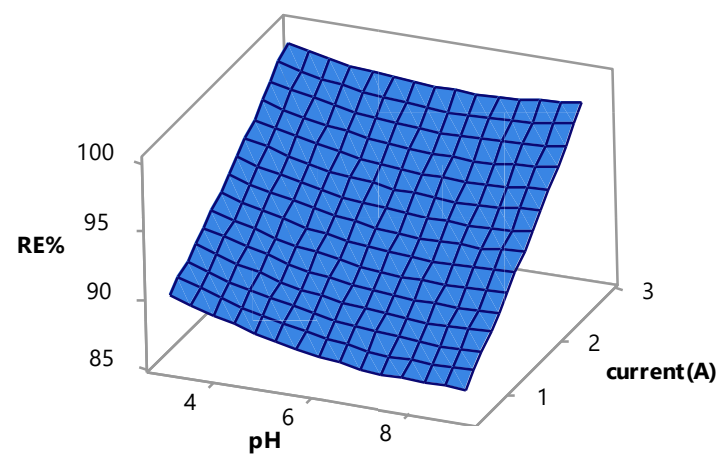

(a)

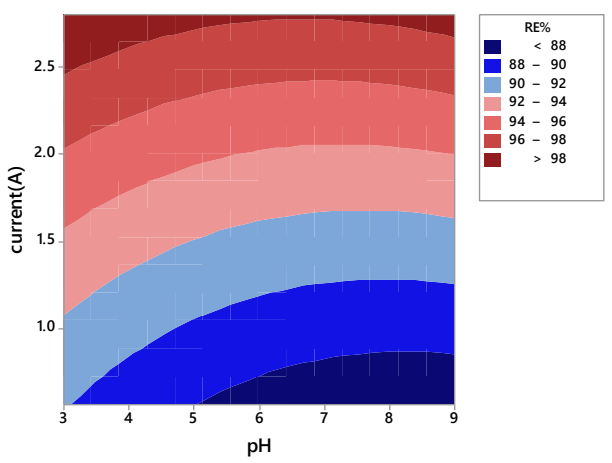

(b)

Figure 3. (a) Response surface plot, (b) contour plot displaying the impact of $\mathrm{pH}$ and current on cadmium ions removal efficiency (hold values: rotation speed $300 \mathrm{rpm}, \mathrm{Cd}$ concentration $=60 \mathrm{ppm}$ )

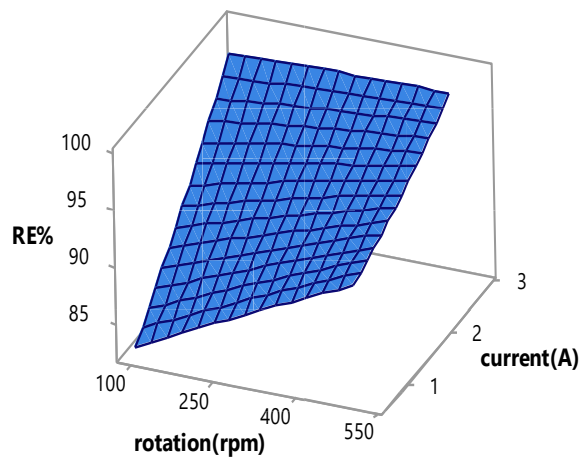

(a)

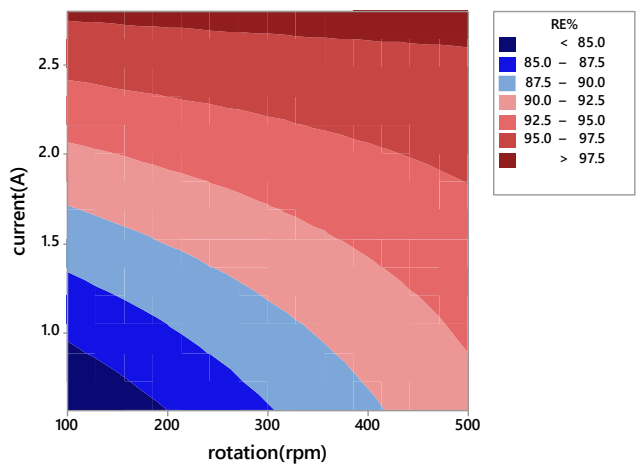

(b)

Figure 4. (a) Response surface plot, (b) contour plot for the effect of rotation speed and current on the cadmium removal efficiency (hold values: $\mathrm{Cd}$ concentration $=60 \mathrm{ppm}, \mathrm{pH}=6$ )

\subsection{The optimization and confirmation test}

In order to reduce the loss in energy and the cost of the treatment to a minimum value, any electrochemical removal system should be conducted to improve operational conditions to give the best possible result. Standards have been established to achieve a specific goal to optimize the system by determining a specific point that improves the basic desire function $\left(\mathrm{D}_{\mathrm{f}}\right)$ by regulating the weight or value that may alter the characteristics of the target. The target variable fields include five options: none, maximum, minimum, objective, and within the range. The objective of Cd removal was set as maximum. The independent factors analyzed in this work were defined within the range of levels to be evaluated. (Cd concentration: 20-100 ppm, current: 0.56-2.8A, rotation speed: $100-500 \mathrm{rpm}$ and $\mathrm{pH}$ value: $3-9$ ). The aim of electrochemical removal of cadmium is to maximize of desire function with the resulting "weight". The value of the upper limit of removal efficacy is set at close to 99 per cent, while the lower value is allocated to 83 per cent. The optimization method has been carried out within such conditions and limits, the results are displayed in Table 6.

Confirmative repeated experiments have been performed using optimized parameters for their validation. Three experiments at the optimum values of the process parameters were performed to confirm the results of optimization tow at $\mathrm{pH} 3$ and one at $\mathrm{pH}$ 7. The results are displayed in Table 7. After $30 \mathrm{~min}$ of the electrolysis, removal efficiency of $99.28 \%$ was achieved at $\mathrm{pH}=3$ and $99.23 \%$ at $\mathrm{pH}=7$ which are in compactable with the range of the optimum value getting from optimization analysis with desirability function of (1) (Table 6). Therefore, the adoption of BBD in connection with the attractiveness feature is 
effective and efficient in optimizing the removal of cadmium by using (PBRCE).

Table 6. Optimum of process parameters for the maximum removal efficiency of cadmium

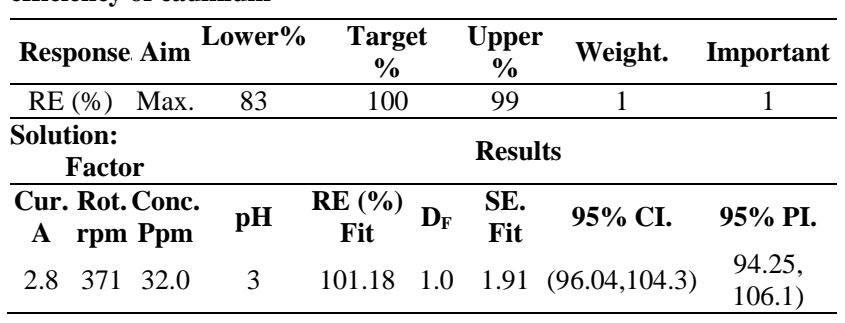

Table 7. Confirmative value for optimum removal efficiency

\begin{tabular}{|c|c|c|c|c|c|c|c|c|c|}
\hline \multirow[b]{2}{*}{ Run } & \multirow{2}{*}{$\underset{\mathbf{A}}{\text { Cur }}$} & \multirow{2}{*}{$\begin{array}{l}\text { Rot. } \\
\text { Rpm }\end{array}$} & \multirow{2}{*}{$\begin{array}{c}\text { Conc. } \\
\text { ppm }\end{array}$} & \multirow[b]{2}{*}{ pH } & \multirow{2}{*}{$\begin{array}{c}\mathbf{E} \\
\text { Volt }\end{array}$} & \multicolumn{2}{|c|}{$\mathrm{R} \mathrm{E}(\%)$ at $30 \mathrm{~min}$} & \multirow{2}{*}{$\begin{array}{l}\text { CE } \\
(\%)\end{array}$} & \multirow{2}{*}{$\begin{array}{c}\text { EC } \\
\text { Kwh/ } \\
\text { kg }\end{array}$} \\
\hline & & & & & & Act. & Avg. & & \\
\hline 1 & 2.8 & & & 3 & & & & 0.44 & 553 \\
\hline 2 & 2. & & & 3 & & & & .44 & כנכ \\
\hline 3 & 2.8 & 371 & 32.0 & 7 & 5.08 & 99.23 & 99.23 & 0.43 & 555 \\
\hline
\end{tabular}

\subsection{Comparison with previous works}

Rotating cylinder electrode of wedge wire screens used for electrochemical removal of cadmium from dilute aqueous solutions has been investigated by Grau and Bisang [42]. In their work, the effects of applied cathodic potential and screen size on the removal of cadmium were analyzed. Cathode potential of $-1.1 \mathrm{~V}$ versus standard calomel electrode (SCE) at (700 rpm) has been applied and taken to be the better value for decreasing $\mathrm{Cd}$ concentration from 54 to $0.9 \mathrm{ppm}$ at the end of 30 minutes of electrolysis with a specific power consumption of $10.7 \mathrm{kWh} / \mathrm{kg}$ and a space velocity of $3.54 \mathrm{l} / \mathrm{h}$. In the present work, the removal level of cadmium was similar to that obtained by Grau and Bisang[42] but starting with lower initial concentration of cadmium (32.0 ppm) at the same time interval (30min) under Glavanostatic conditions (constant current not electrode potential). This is an indication of the good performance of the present rotating cylinder electrode since Glavoanostatic operation mode is the preferred mode on the industrial scale.

The very low current efficiency that was obtained in the present work $(0.44 \%$, Table 7) means that most of the current is consumed for hydrogen evolution as a side reaction. This lower current efficiency is expected since the concentration of cadmium is very low $(32.0 \mathrm{ppm})$, and $\mathrm{pH}$ of the solution is 3. The same observations with respect of lower current efficiency was observed by Reade et al. [43] in their work for cadmium removal using (RVC) rotating cylinder electrode from a solution with the initial concentration of cadmium (56 ppm) in deoxygenated $\mathrm{Na}_{2} \mathrm{SO}_{4}$ at $\mathrm{pH}$ 2. They found that when the concentration of cadmium declined to less than $1 \mathrm{ppm}$ from an initial concentration of $56 \mathrm{ppm}$, the current efficiency declined from $75 \%$ rapidly to reach $20 \%$ as $\mathrm{Cd}$ concentration reached to $3 \mathrm{ppm}$ and then declined further with decreasing the concentration. The new rotating cylinder electrode used in this study showed very satisfactory performance in the removal of cadmium, although the literature reported some values of the current efficiency higher than those in the Glavoanostatic process. However, an additional gain can be obtained from the present work by using hydrogen as a chemical source for other industrial applications when a divided cell design is adopted on the industrial scale.

\section{Conclusions}

High removal efficiency of cadmium from simulated wastewater solution was achieved successfully in the present work by using a rotating tubular packing bed of a woven screen electrode as cathode in a batch electrochemical reactor. The RSM "Box-Behnken "concept has proven to be a very efficient and accurate methodology for optimizing cadmium electrochemical removal. Analysis of ANOVA displayed a high value of $\mathrm{R}^{2}(0.918)$ as a correlation analysis coefficient indicating good agreement between the quadratic model and experimental results. The present results have shown that the current has the main significant effect on the removal efficiency confirming that the electrodeposition reaction is under mass transfer control. Optimum conditions for the process factors were $2.8 \mathrm{~A}$ as current, $371 \mathrm{rpm}$ as rotation speed, $32.0 \mathrm{ppm}$ as initial cadmium concentration, and $\mathrm{pH}$ of 3 . Under these conditions, the concentration of cadmium was decreased from $32.0 \mathrm{ppm}$ to less than $0.3 \mathrm{ppm}$ (RE= 99.28 $\%$ ) in a matter of $30 \mathrm{~min}$ while full removal of Cd was accomplished at 45 min, hence another benefit offered by the present system in term of its ability to complete removal or recover of cadmium from wastewater.

\section{Acknowledgment}

The researchers wish to acknowledge the beneficial and technical assistance received by the staff and technicians at the department of chemical engineering, faculty of engineering-University of Al-Qadisiyah.

\section{REFERENCES}

[1] A. Corami, S. Mignardi, and V. Ferrini, Cadmium removal from singleand multi-metal $(\mathrm{Cd}+\mathrm{Pb}+\mathrm{Zn}+\mathrm{Cu})$ solutions by sorption on hydroxyapatite, Journal of Colloid and Interface Science, 317(2) (2008) 402-408.

[2] Y.-C. Lin, G.-P. Chang-Chien, P.-C. Chiang, W.-H. Chen, and Y.-C. Lin, Multivariate analysis of heavy metal contaminations in seawater and sediments from a heavily industrialized harbor in Southern Taiwan, Marine pollution bulletin, 76(1-2) (2013) 266-275.

[3] M. U. Yaqub and U. A. Shaikh, Near Field Communication Its Applications and Implementation in KSA, King Fahd University of Petroleum \& Minerals. 2012.

[4] W. H. Organization, Cadmium in drinking water, Background document for preparation of WHO guidelines for drinking water quality, (2011).

[5] D. J. Ennigrou, L. Gzara, M. R. Ben Romdhane, and M. Dhahbi, Cadmium removal from aqueous solutions by polyelectrolyte enhanced ultrafiltration, Desalination, 246(1-3) (2009) 363-369.

[6] D. Barnes, Surveys in industrial wastewater treatment, Vol. 3: Manufacturing and chemical industries, (1987).

[7] F. Fu and Q. Wang, Removal of heavy metal ions from wastewaters: A review, Journal of Environmental Management, 92(3) (2011) 407-418.

[8] D. Zamboulis, E. N. Peleka, N. K. Lazaridis, and K. A. Matis, Metal ion separation and recovery from environmental sources using various flotation and sorption techniques, Journal of Chemical Technology \& Biotechnology, 86(3) (2011) 335-344.

[9] B. von Droste, H. Plachter, and M. Rössler, Cultural landscapes of universal value. Gustav Fischer Verlag, 1995.

[10] K. Jüttner, U. Galla, and H. Schmieder, Electrochemical approaches to environmental problems in the process industry, Electrochimica Acta, 45(15-16) (2000) 2575-2594.

[11] O. E. Abdel-Salam, I. M. Ismail, A. Soliman, A. A. Afify, and H. M. Aly, 
Removal of Lead from Industrial Wastewater Using Flow-by-Porous Electrode, Portugaliae Electrochimica Acta, 32(1) (2014) 65-75. G. A. Tonini, R. Martins Farinos, P. F. de Almeida Prado, and L. A Martins Ruotolo, Box-Behnken factorial design study of the variables affecting metal electrodeposition in membraneless fluidized bed electrodes, Journal of Chemical Technology \& Biotechnology, 88(5) (2013) 800-807.

[13] A. K. P. Chu, M. Fleischmann, and G. J. Hills, Packed bed electrodes. I The electrochemical extraction of copper ions from dilute aqueous solutions, Journal of Applied Electrochemistry, 4(4) (1974) 323-330.

[14] G. Issabayeva, M. K. Aroua, and N. M. Sulaiman, Electrodeposition of copper and lead on palm shell activated carbon in a flow-through electrolytic cell, Desalination, 194(1-3) (2006) 192-201.

[15] J. M. Grau and J. M. Bisang, r with rotating cylinder electroRetracted: Effluent treatment using a bipolar electrochemical reactodes of wovenwire meshes, Journal of Chemical Technology \& Biotechnology: International Research in Process, Environmental \& Clean Technology, 84(7) (2009).

[16] S.-H. Chang, K.-S. Wang, P.-I. Hu, and I.-C. Lui, Rapid recovery of dilute copper from a simulated $\mathrm{Cu}-\mathrm{SDS}$ solution with low-cost steel wool cathode reactor, Journal of hazardous materials, 163(2-3) (2009) 544549.

[17] C. A. Basha, M. Somasundaram, T. Kannadasan, and C. W. Lee, Heavy metals removal from copper smelting effluent using electrochemical filter press cells, Chemical engineering journal, 171(2) (2011) 563-571.

[18] I. A. Khattab, M. F. Shaffei, N. A. Shaaban, H. S. Hussein, and S. S. A. El-Rehim, Electrochemical removal of copper ions from dilute solutions using packed bed electrode. Part II, Egyptian Journal of Petroleum, 22(1) (2013) 205-210.

[19] A. H. Abbar, R. H. Salman, and A. S. Abbas, Cadmium removal using a spiral-wound woven wire meshes packed bed rotating cylinder electrode, Environmental Technology and Innovation, 13 (2019) 233-243.

[20] G. W. Reade, A. H. Nahle, P. Bond, J. M. Friedrich, and F. C. Walsh, Removal of cupric ions from acidic sulfate solution using reticulated vitreous carbon rotating cylinder electrodes, Journal of Chemical Technology \& Biotechnology: International Research in Process, Environmental \& Clean Technology, 79(9) (2004) 935-945.

[21] G. Kreysa and R. Brandner, Experiments with a rotating packed bed cell, in Modern Concepts in Electrochemical Reactor Design, Extended Abstracts of the 31st ISE Meeting, 1980, 2.

[22] L.-C. Cheng, W.-L. Chou, C.-P. Chang, Y.-M. Kuo, and C.-T. Wang, Application of response surface methodology for electrochemical destruction of cyanide, International Journal of Physical Sciences, 7(44) (2012) 5870-5877.

[23] H. Sabah, T. Thouraya, H. Melek, and M. Nadia, Application of response surface methodology for optimization of cadmium ion removal from an aqueous solution by eggshell powder, Chemical Research in Chinese Universities, 34(2) (2018) 302-310.

[24] P. Sudamalla, P. Saravanan, and M. Matheswaran, Optimization of operating parameters using response surface methodology for adsorption of crystal violet by activated carbon prepared from mango kernel, Environ. Res, 22(1) (2012) 1-7.

[25] M. Umar, H. A. Aziz, and M. S. Yusoff, Assessing the chlorine disinfection of landfill leachate and optimization by response surface methodology (RSM), Desalination, 274(1-3) (2011) 278-283.

D. Prabhakaran, C. A. Basha, T. Kannadasan, and P. Aravinthan, Removal of hydroquinone from water by electrocoagulation using flow cell and optimization by response surface methodology, Journal of Environmental Science and Health Part A, 45(4) (2010) 400-412. response surface methodology for optimization of azo dye removal by oxalate catalyzed photoelectro-Fenton process using carbon nanotubePTFE cathode, Desalination, 258(1-3) (2010) 112-119.

[28] B. K. Körbahti, Response surface optimization of electrochemical treatment of textile dye wastewater, Journal of hazardous materials, 145(1-2) (2007) 277-286.

[29] A. Ostovan, M. Ghaedi, M. Arabi, and A. Asfaram, Hollow porous molecularly imprinted polymer for highly selective clean-up followed by influential preconcentration of ultra-trace glibenclamide from bio-fluid, Journal of Chromatography A, 1520 (2017) 65-74.

[30] A. Ostovan, M. Ghaedi, and M. Arabi, Fabrication of water-compatible superparamagnetic molecularly imprinted biopolymer for clean separation of baclofen from bio-fluid samples: a mild and green approach, Talanta, 179 (2018) 760-768.

[31] K. Thirugnanasambandham, V. Sivakumar, and M. J. Prakash, Treatment of egg processing industry effluent using chitosan as an adsorbent, Journal of the Serbian Chemical Society, 79(6) (2014) 743-757.

[32] J. H. Hemeidan and A. H. Abbar, Electrochemical removal of copper from a simulated wastewater using a rotating tubular packed bed of woven screens electrode, Al-Qadisiyah Journal for Engineering Sciences, 12(2) (2019) 127-134.

[33] R. E. Sioda, Mass transfer problems in electrolysis with flowing solution on single and stacked screens, Journal of Electroanalytical Chemistry and Interfacial Electrochemistry, 70(1) (1976) 49-54.

[34] D. W. Green and R. H. Perry, Section 2: Physical and Chemical Data, Perry's Chemical Engineers' Handbook; Perry, RH; Green, DW, Eds, (2008).

[35] A. H. Sulaymon, S. A. M. Mohammed, and A. H. Abbar, Cadmium removal from simulated chloride wastewater using a novel flow-by fixed bed electrochemical reactor: Taguchi approach, DESALINATION AND WATER TREATMENT, 74 (2017) 197-206.

[36] M. A. Bezerra, R. E. Santelli, E. P. Oliveira, L. S. Villar, and L. A. Escaleira, M.A. Bezerra, R.E. Santelli, E.P. Oliveira, L.S. Villar, L.A. Escaleira, "Response surface methodology (RSM) as a tool for optimization in analytical chemistry," Talanta 76(5), 965-77, 2008., Talanta, 76(5) (2008) 965-977.

[37] M. Evans, Optimisation of manufacturing processes: a response surface approach, 791. Maney Pub, 2003.

[38] Y.-D. Chen, W.-Q. Chen, B. Huang, and M.-J. Huang, Process optimization of K2C2O4-activated carbon from kenaf core using BoxBehnken design, Chemical Engineering Research and Design, 91(9) (2013) 1783-1789.

[39] K. Yetilmezsoy, S. Demirel, and R. J. Vanderbei, Response surface modeling of $\mathrm{Pb}$ (II) removal from aqueous solution by Pistacia vera $\mathrm{L}$.: Box-Behnken experimental design, Journal of Hazardous Materials, 171(1-3) (2009) 551-562.

[40] L. Huiping, Z. Guoqun, N. Shanting, and L. Yiguo, Technologic parameter optimization of gas quenching process using response surface method, Computational Materials Science, 38(4) (2007) 561-570.

[41] J. Segurola, N. S. Allen, M. Edge, and A. Mc Mahon, Design of eutectic photoinitiator blends for UV/visible curable acrylated printing inks and coatings, Progress in Organic Coatings, 37(1-2) (1999) 23-37.

[42] J. M. Grau and J. M. Bisang, Electrochemical removal of cadmium from dilute aqueous solutions using a rotating cylinder electrode of wedge wire screens, Journal of applied electrochemistry, 37(2) (2007) 275-282.

[43] G. W. Reade, P. Bond, C. Ponce de Leon, and F. C. Walsh, The application of reticulated vitreous carbon rotating cylinder electrodes to the removal of cadmium and copper ions from solution, Journal of Chemical Technology and Biotechnology, 79(9) (2004) 946-953. 